\title{
Constitution of Innovation and Entrepreneurship Education System in the Open Universities
}

\author{
Wei $\mathrm{Wu}^{1, \text { a }}$, Yuehua Zhang ${ }^{2, \mathrm{~b}}$, Xue Wang ${ }^{3, \mathrm{c}}$, Lan $\mathrm{Li}^{4, \mathrm{~d}}$, Jingni $\mathrm{Yu}^{5, \mathrm{e}}$ and \\ Lihong Yue ${ }^{6, f}$ \\ ${ }^{1,5.6}$ College of Life Science, Jiamusi University, Jiamusi, Heilongjiang Province, China \\ ${ }^{2,3.4}$ College of Science, Jiamusi University, Jiamusi, Heilongjiang Province, China \\ a925442245@qq.com, bzhangyaohua_2008@163.com, c272963208@qq.com, \\ d171815722@qq.com, 'yuelihong64@163.com, '896661700@qq.com
}

\begin{abstract}
Keywords: Constitute, the Open University, innovation and entrepreneurship education; system construction.

Abstract. The education regarding innovation and entrepreneur- ship with its own significant strategic importance and value of education has attracted wide attention, and were recognized by most ordinary colleges. Similarly, it is also very significant for the Open University to develop innovative and entrepreneurial education. It is paramounted that teachers, families and other factors dominate. According to the characteristics of the Open University, innovation and entrepreneurship education system consists of curriculum system, system performance, and utility and safety systems. This makes the combination of innovation and entrepreneurship education and professional education in Open University to satisfy the needs of students, to set the whole process of personal training and improve their overall quality and ability.
\end{abstract}

\section{Introduction}

The education regarding innovation and entrepreneurship is a new trend for education development and reform in the world. It offers the concept of education, personnel training and other aspects of the tremendous impact to our nation's education system colleges and universities [1]. As an open university established newly, it is a teaching model for long-term and web-based scholars and adult charge. These are two points different from ordinary universities that open universities to carry out innovation and entrepreneurship education [2]. It really makes sense that we should how to build it between ordinary colleges and universities and what difference will make it. All of which we need is to combine the characteristics of the Open University to do in-depth study. It is vague and presented fringing to subject the positioning of innovation and entrepreneurship education. The most colleges and universities haven't been aware of how to develop innovation and entrepreneur ship education, thus forming a blur build innovative and entrepreneurial education system and personnel training system. Therefore, innovation and entrepreneurship education has not been taken into academic discipline construction planning, personnel training intentions, other than the daily teaching quality assessment system account [4].

Innovation and entrepreneurship education and professional education system are separated. Currently, most colleges and universities don't practice the innovation and entrepreneurship education into the professional personnel training and education system [5]. There are separate for innovation and entrepreneurship education and professional personnel training and education systems. Generally, it's agreed that innovation and entrepreneurship education and professional education had no association, not realizing professional educational system to become a bearer or a carrier, and no concept of innovation and entrepreneurship education to penetrate into the formation of a systematic professional education curriculum [6].

It lacks resources and methods regarding innovation and entrepreneurship education. There are some examples that the lack of good teachers. Innovation and entrepreneurship education teachers not only need to have extensive theoretical knowledge but also a rich social experience and practical experience. Simultaneously, it is short of good teaching resources. Currently, innovation and 
entrepreneurship education are weak quality courses and curriculum resources sharing level even lower than some misnamed innovative curriculum. Finally, rich enough teaching practice teaching is invariably at a disadvantage. In most universities, teaching innovation and entrepreneurship education courses mainly theoretical teaching and giving rise to analysis, these do not attract students can not meet the needs of education in a simplified form.

\section{Construction Advantages of innovation and entrepreneurship education system in Open University}

It is based in the education to carry out all of life-long in Open University. Training Target to the Open University is to combine mutual knowledge with ability. The professional education and vocational education is based on actual talent [7]. The education of the Open University is present in both the professional education institutions and higher vocational colleges, which consists of professional knowledge and professional skills to implement vocational education, and it is a kind of education for sustainable development. It demonstrates Open University to build innovative entrepreneurship education system to meet its own goal of building a culture and purpose, and this is very paramount. Open University Innovation and Entrepreneurship Education contrast to the common institutions of students, teachers, and families. There are three advantages: in the first, the Open Universitys students are adults with work experience and even some who have entrepreneurial experience, so the Open University's students have a certain experience of innovation and entrepreneurship experience [8]. On the one hand, adult students have a major economic base to support the development of innovation and entrepreneur- ship training. On the other hand, the adult students will invariably feel the pressure from life and work, and their desire to change their lives or create their own value through learning [9]. There is one more point I should touch on that, the teachers, the implementation of the open university teacher education, employment and the ability to hire the experienced and entrepreneurial, business executives and entrepreneurs. They teach students the remote by placing online video, so you can make up for the lack of teachers in ordinary school. The defects were especially conducive to innovation and entrepreneurship in education. The the last but not the least, in the family, college students are eager for innovation and entrepreneurship, but the family does not support their business, because their parents believe that even a very good start, but there is still risk. And there is often a huge initial venture capital investment. The probability of success is forlorn in most of the adult Open University [10].

\section{Training objectives the Open University innovation and entrepreneurship talents.}

It is the main purpose that talents intent to binding "General entrepreneurship education" quality training to make entrepreneurship as a core, and "narrow the scope of entrepreneurship education" for special entrepreneurial skills training and commercial operation. Not only improve it the entrepreneurship and entrepreneurial awareness of students, but also enrich their knowledge of entrepreneurship, promote their entrepreneurial capacity and enable them to become all-round talent. It can make students adapt to business environment quickly, have a strong entrepreneurial capacity and a courage active student guide. They choose the right industry and encourage innovation and cultivate their ability to develop their industry. The accumulation of entrepreneurial experience, and ultimately make them become professional personnel on the innovation and entrepreneurship.

We focus on the characteristics of the Open University and proposed by the system of innovation and entrepreneurship education curriculum, system capacity, practical system, security system components. The general idea is to adhere to people-centered scientific concept of development. The development of students as the foundation, lets innovation and entrepreneurship education useful to all students, combined with professional education, promote the comprehensive development of students, it has a professional technology. 


\section{Curriculum structure}

In the curriculum, we follow two principles: first, innovation and entrepreneurship is a multidisciplinary integrated curriculum requires interdisciplinary and creative curriculum design. Innovation and entrepreneur- ship bring the concept of professional. Teaching also requires a complementary and comprehensive teaching various disciplines, emphasizing the combination of theoretical courses and practical courses so as to form a rich content, operational innovation and entrepreneurship education curriculum; Otherwise, the innovation and entrepreneurship education should be different from the usual school curriculum that teach students to select professional courses, the main content, teaching methods and other aspects etc. It should be clear, in order to confirm the validity and breadth of learning content for students of innovation and entrepreneurship education. Course System in the Open University takes the form of a modular curriculum team; we build public basic module, professional module, a practice module, and common module four modules. Public basic course module focuses on the culture of innovation and the spirit and consciousness of entrepreneurship. Professional innovation and entrepreneurship courses should be combined with specialized courses, when a curriculum based on their characteristics to build their expertise. It aims at enrich students' knowledge-based entrepreneurial knowledge and skills. Practice course focuses on improving the practical ability of innovation and entrepreneurship. For students, common curriculum be able to demonstrate case innovative open case studies, business seminars, as well as examples of creative development. In teaching methods, the main line of innovation and entrepreneurship process replaces the main management functions of traditional teaching methods.

\section{Ability System}

Innovation and entrepreneurship system is the core of the education system. According to the characteristics of open universities, we promote self-learning ability, professional competence, innovation and entrepreneur- ship, the ability to develop three systems. Refers to the ability to self-learning ability is meant scholars under the guidance of teachers, according to their intentions, objectives, plans, their own use a variety of learning media acquire knowledge and skills needed in a network environment. This is a comprehensive, integrated learning, including self-planning, self-control, and self-assessment skills. Independent learning ability levels directly reflect the quality of learning outcomes and teaching.

Professional competence is the ability to engage in certain professional practitioners, staff must have the ability to include vocational closely related to professional competence. Among them, the expertise involved in the necessary work skills and knowledge workers are competent and the basic ability to survive basis of this work. Professional competence means in the skills and methods of professional activity required, which workers acquire new knowledge and skills in his career, learning new methods has paramounted significance. Social competence refers to the effective capacity through professional activity obtained for workers, which is the basic quality of the activities in the workplace.

Innovation capacity refers to the knowledge, experience in science learning, new ideas, new concepts, new knowledge, and new systematic approach and apply to solve new problems for the foundation. Entrepreneur- ship includes two aspects; one is the ability and capacity of relevant opportunities involved, including the ability to identify market opportunities, development opportunities. Another is the daily operation and management capabilities, including production capacity, marketing capability, technical capacity, and resource allocation capability and so on. These three criteria influence each other, complement each other and form the innovation and entrepreneurship education system together. Self-learning ability is the foundation, is the core of professional competence, innovation and entrepreneur- ship is the ultimate goal. 


\section{Practice system}

The implementation of innovative entrepreneurship education needs to have a strong security system; otherwise it will be formidabled to achieve training objectives. The construction safety systems from the aspects of security staff, teaching resources, security management operations, as well as the specific behavior, is beneficial to the formation of three interacting safety systems. Innovative teaching staff is to ensure that entrepreneur- ship education. Open University faculty innovation and entrepreneurship education not only needs a double qualified team, but also very familiar with the concept of distance education and teaching methods. Therefore, building Open University colleges insists on two aspects of walking. On the one hand, we should develop own teacher's experience. Teachers need a certain time each year in-depth business, to be familiar with the business; on the other hand, having talked regarding entrepreneurship courses should hire entrepreneurial experience and has held a teacher or teacher classroom seminars. Based on personal experience of successful entrepreneurs, business students and encourage them to teach students practical experience.

Open University teaching resources should be student-centered, according to the teaching content and design needs of students, and students should consider the cultural level, level of intelligence, the ability to accept and learn the characteristics and laws of physical and mental development. To achieve four objectives: first, we should help students achieve effective learning, so that the students can spend the least time gaining more knowledge. Make them learn more fun and life practice closer together. There is one more point I should touch on that, when and where to help achieve the goal of learning can be in order to make the digital resources in a variety of mobile terminals spread. The last but not the least, it is to achieve self-help and mutual influence. Fourth, it can help students develop practical skills.

Its main task is to perform theoretical investigation innovation and entrepreneurship education, to draft policies, which can encourage and support college students venture, to stimulate students' entrepreneurial potential and to create a good business climate; its mission is to detect and guide students in entrepreneurial projects. The establishment of special for the students start Fund aid students' science, technology and invention of their own businesses; its mission is to build entrepreneurial information service network and establish entrepreneurial information tracking system that can collect feedback from students and out of school, with the help of student feedback, timely adjustment of innovation entrepreneurship education system, and it will improve the quality of teaching innovation and entrepreneurship education continuously.

\section{Conclusion}

It is a new subject that the Open University performs innovation and entrepreneurship education. We focus on properties to build and the Open University innovation and entrepreneurship education system in the Open University, which contain public basic courses, professional courses, practical courses and general courses. There are four course modules including self-learning ability, professional competence, innovation and entrepreneurship education capacity. These are three progressive systems that including schools, commercial and social trinity practice system. The safe things contain the teaching staff, teaching resources, security, management, operational safety of these three interacting safety systems. In this paper, innovation and entrepreneur ship education system also needs to open the actual operation of the system at the university and constantly to be corrected based on practical results. We hope to open the University of innovation and entrepreneurship education to enhance students' overall quality and ability to innovate, so that improves the quality of education in the Open University.

\section{Acknowledgements}

Fund Project: The key project of 2015 in "Twelfth Five-Annual Plan", Heilongjiang Province of Education Science, №: GJB1215080. 


\section{References}

[1] Zhao Y. Who's Afraid of the Big Bad Dragon: Why China Has the Best (and Worst) Education System in the World [M]. John Wiley \& Sons, 2014.

[2] Boulos A. Conceptualisation of constraints on creativity in teaching in higher education: Towards the possibility of challenging practices in an Irish university[D]. , 2013.

[3] Lee M H. A tale of two cities: Comparing higher education policies and reforms in Hong Kong and Singapore[J]. Australian Journal of Education, 2002, 46(3): 255-286.

[4] Achieving quality learning in higher education[M]. Routledge, 2012.

[5] Drucker P. Innovation and entrepreneurship [M]. Routledge, 2014.

[6] Laukkanen M. Exploring alternative approaches in high-level entrepreneurship education: creating micromechanisms for endogenous regional growth [J]. Entrepreneurship \& Regional Development, 2000, 12(1): 25-47.

[7] Powell J J W, Bernhard N, Graf L. The emergent European model in skill formation comparing higher education and vocational training in the Bologna and Copenhagen processes [J]. Sociology of Education, 2012, 85(3): 240-258.

[8] Maguire H, Mc Cloat A, O’Donoghue M, et al. Using Images And Objects As A Tool For Teaching Education For Sustainable Development And Responsible Living In Home Economics[J]. Enabling Responsible Living, 2011, 14(15.00): 171.

[9] Senge P M, Cambron-McCabe N, Lucas T, et al. Schools that learn (updated and revised): A fifth discipline fieldbook for educators, parents, and everyone who cares regarding education $[\mathrm{M}]$. Crown Business, 2012.

[10] Boyd D. Why youth (heart) social network sites: The role of networked publics in teenage social life $[\mathrm{J}]$. MacArthur foundation series on digital learning-Youth, identity, and digital media volume, 2007: 119-142. 